|Research Article / Araştırma Makalesi|

Scientific Studies on Laboratory Based Learning Approach

\title{
Laboratuvar Tabanlı Öğrenme Yaklaşımına ilişkin Bilimsel Çalışmalar
}

\section{Fatih Serdar Yıldırım ${ }^{1}$}

\section{Keywords}

1. Science education,

2. Laboratory-based learning

3. Laboratory in science education

Anahtar Kelimeler

1. Fen eğitimi

2. Laboratuvar tabanlı öğrenme

3. Fen eğitiminde laboratuvar

\section{Received / Başvuru}

Tarihi

24.07.2020

Accepted / Kabul Tarihi 04.01.2021

\begin{abstract}
Purpose: Among the main objectives of the science curriculum are to raise individuals who research and question, to make the individual realize the importance of safety in scientific studies and to contribute to applications in science. In line with this goal, in science; it is important to bring students to the level of inventions and innovations by providing an interdisciplinary perspective to problems by integrating them with mathematics, technology and engineering. It is possible for students to create products by using the knowledge and skills they have acquired, to determine how to add value to these products, and to create products from their studies by using the laboratory-based learning approach in science teaching (MEB, 2018). The aim of this study is to examine the studies carried out in the field of science education on the Laboratory-Based Learning Approach in terms of some variables, especially between the years $2010-2020$.

Design/Methodology/Approach: 144 studies were reached in the study. These studies consisted of 69 articles, 53 master theses and 22 doctoral dissertations on laboratory-based learning approach. Document analysis method was used in this study. The obtained data were analyzed with the descriptive analysis method and the results were given as percentage and frequency values.

Findings: Scientific studies related to the Laboratory-Based Learning Approach in Science education were carried out mostly in article type $(48 \%)$, then in the type of master thesis (37\%) and in the type of doctoral thesis $(15 \%)$. In articles and postgraduate theses on Laboratory-Based Learning between 2010 and 2020, it was observed that the studies were mostly conducted in 2017 (13.2\%) and at least in 2020 (1.4\%). However, it is seen that the studies on Laboratory Based Learning gained momentum between 2017 and 2019.

Highlights: According to the results of this study; In studies conducted in the field of laboratory-based science education, it has been observed that quantitative research methods are often preferred. Publications in the type of articles are more than master's and doctoral theses, the studies mainly focus on the subject of "The effect of various methods applied in the laboratory on laboratory attitudes", that the most sample group in these studies are teacher candidates and the most preferred measurement tool is "success test" It has been determined.
\end{abstract}

Öz

Çalışmanın Amacı: Fen Bilimleri öğretim programının temel hedefleri arasında araştıran ve sorgulayan bireyler yetiştirmek, bireye bilimsel çalışmalarda güvenliğin önemini fark ettirmek ve fen alanındaki uygulamalara katkı sağlama yer almaktadır. Bu hedef doğrultusunda fen bilimlerini; matematik, teknoloji ve mühendislikle bütünleştirmeyi sağlayarak, problemlere disiplinler arası bakış açısı kazandırılarak öğrencileri buluş ve inovasyon yapabilme seviyesine ulaştırmak önemsenmektedir. Öğrencilerin, edindikleri bilgi ve becerileri kullanarak ürün oluşturmaları, bu ürünlere nasıl katma değer kazandırılabileceklerini belirlemeleri ve çalışmalarından ürün oluşturmaları laboratuvar tabanlı öğrenme yaklaşımının fen öğretiminde kullanımı ile mümkündür (MEB,2018). Bu çalışmanın amacı özellikle 2010-2020 yılları arasında, Laboratuvar Tabanlı Öğrenme (laboratory-based learning )Yaklaşımına ilişkin fen eğitimi alanında gerçekleştirilmiş çalışmaları bazı değişkenler açısından incelemektir.

Materyal ve Yöntem: Çalışmada 144 çalışmaya ulaşılmıştır. Bu çalışmalar; laboratuvar tabanlı öğrenme yaklaşımı ile ilgili 69 makale, 53 yüksek lisans tezi ve 22 doktora tezinden oluşmaktadır. Bu araştırmada kullanılan yöntem doküman incelemesidir. Elde edilen verilerin analizi, betimsel analiz ile gerçekleştirilmiştir. Ulaşılan sonuçlar ise yüzde ve frekans değerleri şeklinde verilmiştir.

Bulgular: Laboratuvar Tabanlı Öğrenme Yaklaşımıyla ilgili olarak yürütülen bilimsel çalışmalar daha çok makale türünde (\%48), ardından yüksek lisans tezi türünde (\%37) ve en az ise doktora tezi türünde (\%15) gerçekleştirilmiştir. 2010-2020 yılları arasındaki Laboratuvar Tabanlı Öğrenmeyle ilgili olarak makale ve lisansüstü tezlerinde kin çalışmaların daha çok 2017 yıllarında (\%13,2), en az ise 2020 (\%1,4) yılında yürütüldüğü görülmüştür. Bununla beraber Laboratuvar Tabanlı Öğrenmeyle ilgili çalışmalar 2017 ve 2019 yılları arasında bir ivme kazandı̆̆ı görülmektedir.

Önemli Vurgular: Bu çalışmanın sonuçlarına göre; laboratuvar tabanlı fen eğitimi üzerine yapılan çalışmaların genelinde nicel araştırma yöntemlerinin sıklıkla kullanıldığı görülmüştür. Makale türü yayınlar yüksek lisans ve doktora tezlerine göre daha çok olup, çalışmalarda yaygın olarak "Laboratuvarda uygulanan çeşitli yöntemlerin laboratuvar tutumlarına etkisi” konusunun araştırıldığı, bu çalışmalarda en fazla seçilen örneklem grubunun öğretmen adaylarından oluştuğu ve en fazla tercih edilen ölçme aracı olarak ise "başarı testi" kullanıldığı tespit edilmiştir.

\footnotetext{
${ }^{1}$ Corresponded Author, Akdeniz University Faculty of Education, Science Education Department, Antalya,Turkey; https://orcid.org/ 0000-0003-4080-8488
} 


\section{INTRODUCTION}

As in other countries around the world, in Turkey laboratory use is undoubtedly one of the most effective tools for meaningful learning for education in such fields as science, physics, chemistry and biology. The purpose of laboratory applications in education can be summarized as increasing students' interest and curiosity, developing creative thinking, critical thinking and problem solving skills, supporting their conceptual development, developing scientific process skills such as data collection, observation, and interpretation of results (Aydoğdu, 2003; Azizoğlu and Uzuntiryaki, 2006). The use of laboratories in science lessons at primary and secondary level and the process of developing laboratory skills began in the 1800s with the effects of European educators such as Pestalozzi, Froebel and Spencer (Sunal et al., 2008; Yanarateş \& Yılmaz, 2020). Later, with the studies of educational researchers such as Jerome Bruner, Joseph Schwab, Piaget and Vygotsky, the approach to "practice" in laboratory use has been replaced by laboratory approaches based on inquiry and research since the 1980s. In its definition, scientific knowledge is stated to be an objective, provable, universally consistent and systematic stack of information. The "Science Class Laboratory Applications" course started in the undergraduate program in 1997 in Turkey, has aimed to help prospective teaches acquire basic skills concerning laboratory skills, have knowledge in laboratory studies, and help their students reach the scientific knowledge aimed (Baştuğ, Çıkılı, Yalçın and Polat, 2002). It is seen in international studies such as PISA that science teaching is not effective enough if the theoretical information cannot be concretized and connected with daily life. Students should feel themselves in an enjoyable and exciting learning environment in transforming their abstract knowledge into concrete and making meaningful and permanent learning by connecting with the events of daily life. Labs are best practices in such environments. (Çepni et al., 2011).

By adopting a holistic perspective in terms of learning-teaching theories and practices in the 2018 Science Curriculum; in general, a learning strategy based on inquiry and knowledge transfer, in which students are responsible for their own learning, active participation in the learning process, is taken as a basis. In this way, a Laboratory-Based Learning-based program was prepared in which learning environments, experiments and observations are priorities, and learning by doing and experiencing is supported so that students can learn information meaningfully and permanently (MEB, 2018). In science education, it is necessary to attach importance to laboratory studies and to plan laboratory studies and activities carefully and in accordance with the purpose in order for educational activities to reach the targeted point. We can accept science as a group of disciplines that reveal the causes and consequences of events and situations, produce scientific information, by examining the relationships of living and non-living environments, and the relationships of the living and non-living environment. Various techniques and methods are used in science education to transfer the interaction of entities with the environment and the network of relationships to students. Among these methods and techniques, the importance of the laboratory and its place in terms of science is a known fact.

Özmen et al. (2005) emphasized the importance of laboratory applications in science education as follows:

- Concretizing abstract concepts in science and gaining experience with concrete materials

- Helping students learn the scientific method such as working methods, problem solving, analysis and generalization

- Developing students' special abilities and psycho-motor skills

- Ensuring students develop a positive attitude towards science and experimental method

- Teaching students the experimental method of science

- Giving the idea that knowledge can be reached in a sequential order and that known theory and models can change over time

The fact that the laboratory takes part in the student's science education adventure can contribute positively to the teaching process. In addition to teaching the relevant acquisition to the student, it can be thought that the laboratory environment will have a positive effect on the process and a facilitating role in teaching the student the scientific process awareness, understanding the position of science in life, accessing and discovering information, technical knowledge and manual skills. Approaches related to the usage purposes of the laboratory in science education can be grouped in five groups in general. These are respectively;

1. Validation (deductive) approach

2. Inductive approach

3. Scientific process skills approach

4. Technical skills approach

5. Invention approach (Şahin and Çepni, 2001).

When the contents of the approaches presented above are examined, the importance of laboratories for science education and the benefits of the students with the use of laboratories are revealed more clearly.

1. Validation approach: It deals with the proof of existing knowledge and its justifications, the causes and effects of the book knowledge and the learning situations that the student confronts. This approach is the most commonly used approach in science teaching. This approach requires that the concept, principle, law or hypothesis covered in the course be proven in the laboratory by the students or the teacher. In other words, the teacher tries to verify what is taught in the classroom in the laboratory (Aydoğdu, B. 2009). In this approach, the student is given what to find and how to find it, what to do at 
which intermediate step, and it is expected to be followed exactly in the laboratory. In addition, what the student has to find is given in advance. It corresponds to closed-ended experiments from the experiment types.

2. Inductive approach: With the scientific fact that the student encounters for the first time and the experimental study, the learning is based on the student's discovery of information. In other words, students are enabled to obtain information through their own activities in a teaching-learning environment prepared by the teacher. What will come out of the experiment is not given in advance. The inductive approach corresponds to the open-ended experiment type and the student is not told what will come out of the experiment. However, the tools and materials required in the experiment are determined by the teacher. It is up to the student to conduct the experiment, save the data, analyze and interpret the data. As a result of this process, the student should make a generalization revealing a physics / chemistry law or principle. (Bloody, U., \& Yağbasan, R., 2008).

3. Scientific process skills approach: The studies conducted on students' acquisition of skills such as observation, classification, association, mathematical connections, measuring, presenting results and evaluating, predicting, making definitions, evaluating process variables, interpreting, planning experiments and carrying out planned experiments, and their recognition of the scientific process are in the foreground (Çepni et al., 1994). While planning activities related to scientific process skills, not all skills can be developed with a single activity. In some cases, activities can be planned to develop even a single skill in the student. However, during the implementation of this approach, simple cognitive processing skills are developed first, because these skills can facilitate the development of more complex skills. Technical skills approach: As the name suggests, studies are carried out that set goals regarding the use of laboratory equipment and aim at gaining technical skills to the student. The purpose of this approach is to use some equipment used in experiments or to gain technical skills related to the ability to set up an experiment, because the students should have prior knowledge about what the experiment equipment is and about setting up an experiment setup before doing the experiment. This approach requires the use of the laboratory to develop technical skills related to the use of some special tools and setting up experimental setups. Thanks to this approach, students' ability to carry out activities in science classes improves. Thus, students' learning is indirectly helped (Çepni et al., 2006; Köse, 2008).

4. Invention approach: As a principle, experimental work on a scientific reality is aimed to be as original as possible, in which the students fictionalize and apply on their own. Our students should not be deprived of the benefits of these approaches, which can be included in education and training processes in a healthy way with the active use of the laboratory environment. Science laboratory activities and studies, which are built around these approaches, will be activities and studies that will facilitate the teacher's job in bringing our students to the desired scientific perspective and awareness level (Özmen \& Yiğit, 2006; Köse, 2008).

This study was carried out with the aim of analyzing the research articles in national journals according to the variables determined by the graduate and doctoral theses indexed in the Institute of Higher Education - National Thesis Center covering the years 2010-2020, indexed in ULAKBIM Social Sciences Database and accessed from Google Scholar Database. In this study, scientific studies made on the subject of Laboratory Based Teaching in teaching of physics, chemistry, biology and science in Turkey are analyzed in terms of publication type, research method, sample group, unit covered, types of data collection tools selected and publication year. In this respect, the research is a study that is thought to contribute to the literature by determining the status of the research about Laboratory-Based Teaching over a period of ten years. With the results of the study, it is aimed to identify possible deficiencies and deficiencies in this field and to shed light on future studies. For this reason, it is thought that the study will be a source for future research, since it lists the studies about Laboratory-Based Teaching in science education in the last decade. For this purpose, the questions in the research were formed as follows:

Along with the fields of physics, chemistry, and biology, the following questions are asked for the studies conducted in science education during 2010-2020 related to Laboratory-Based Teaching;

1. What is the distribution in terms of the type of publication?

2. What is the distribution in terms of publication type and years?

3. What is the distribution in terms of research method?

4. What is the distribution of the type of publication and research method over the years?

5. What is the distribution of research methods over the years?

6. What is the type of publication and the distribution of the selected sample group?

7. What is the distribution of the type of publication and the data collection tool selected?

8. What is the distribution according to the type of publication, sample group chosen and the unit dealt with?

\section{Limitation of the Research}

In this study, it was aimed to examine the studies on Laboratory Based Teaching in the field of science education. For this purpose, the research is limited to the studies in the field of science. In addition, it has been limited to the studies of the last ten years, with 
the idea of determining how researchers' tendencies have changed until 2020 and because the studies reached are requested to be up-to-date. However, the fact that 2020 has not yet ended when this study is completed is another limitation of this study.

\section{METHOD}

\section{Research Pattern}

Document analysis was used as a data collection method in the study. Document analysis, as a research tool, aims to collect documents that will be research data, to examine, question and analyze these documents (O'Leary, 2017). Document analysis is an effective method and data can be obtained in a short time compared to other research methods, so it is more efficient (Koyuncu et al, 2018).

\section{Data Collection Process}

The universe of the study consists of articles, master theses and doctoral theses published in science education based on "Laboratory Based Learning Approach" during 2010-2020. In the literature review, while the National Thesis Center is used for accessing master's thesis and doctoral dissertations, ULAKBIM Social Sciences Database and Google Scholar databases were searched for national articles. During the screening, the keywords "laboratory-based learning", "laboratory-based science education", "laboratory-based education" were used. As a result of this search, a total of 144 publications including 69 articles, 53 master's theses, 22 doctoral dissertations were examined in the research. It was paid attention to whether the articles obtained were composed of any master's or doctoral thesis.

\section{Analysis of Data}

Descriptive analysis was used to analyze the data obtained in the study. The main purpose of descriptive analysis is to summarize and interpret the data obtained as a result of the research within the framework of the determined themes. The obtained analysis findings are first systematically organized, interpreted and some results are reached. The researcher can make predictions by interpreting the results (Yıldırım \& Şimşek, 2016).

The results obtained from the analysis of the data are reflected as percentage and frequency values. The results were graphically presented and interpreted in the year of publication, type of publication, method, sample group and subject categories.

\section{FINDINGS}

In this section, articles, master's theses and doctoral dissertations made in Turkey between 2010-2020 on approach of research and inquiry based learning approach in science teaching are analyzed in terms of publication type, publication year, research method, sample group, units and subject covered and type of the measurement tool. The results are expressed and interpreted descriptively as percentages and frequency values in tables and graphics.

In Figure 1, the distribution of the studies related to the Laboratory Based Learning Approach in terms of the type of publication is presented.

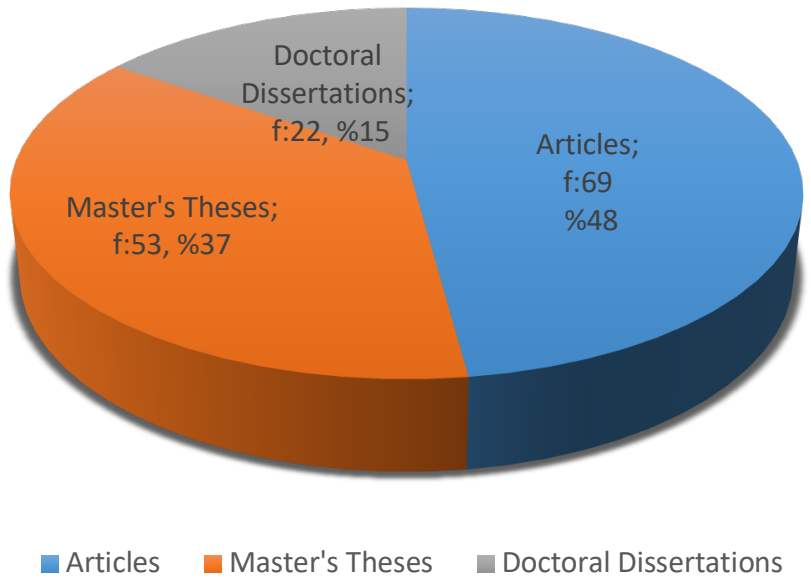

Figure 1: Distribution of studies on laboratory-based learning approach between 2010 and 2020 in terms of publication type 
As a result of the examination of Figure 1, scientific studies related to the Laboratory-Based Learning Approach in Science education were carried out mostly in article type (48\%), then in the type of master thesis (37\%) and at least in the type of doctoral thesis (15\%). The distribution of the studies on Laboratory Based Learning according to the type of publication and years is presented in Figure 2.

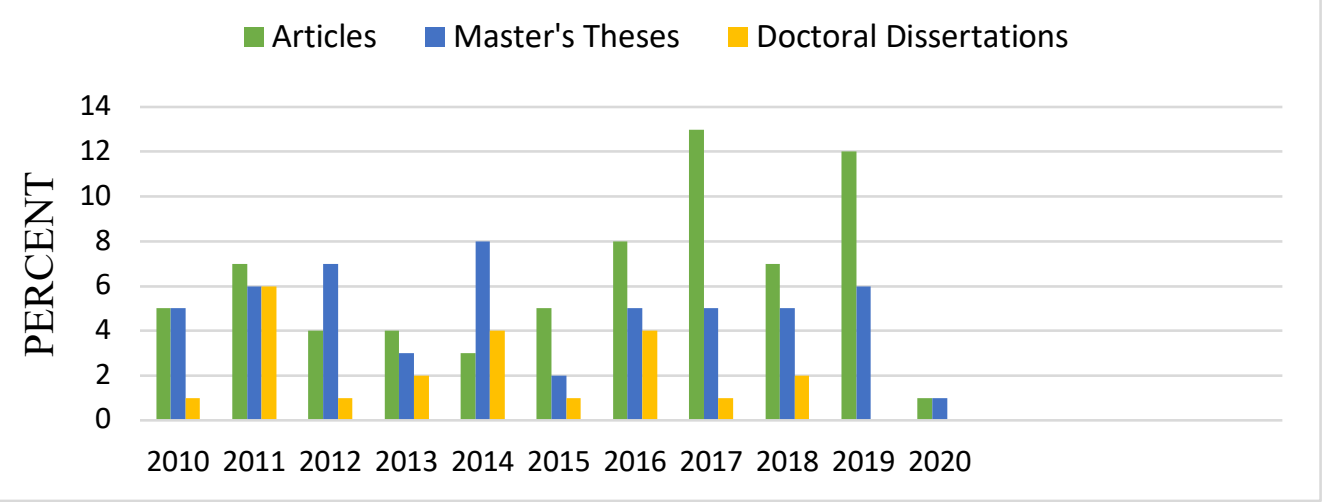

Figure 2:Distribution of the type of publication by years of studies on laboratory-based learning approach between $2010 / 2020$

In articles and postgraduate theses on Laboratory-Based Learning between 2010 and 2020, it was observed that the studies were mostly conducted in 2017 (13.2\%) and at least in 2020 (1.4\%). However, it is seen that the studies on Laboratory Based Learning gained momentum between 2017 and 2019. Considering the years in which it was mostly conducted in terms of the type of publication, it is seen that the article type was made in 2017 (13.2\%), the postgraduate type in 2014 (7.6\%), and the doctoral type in 2011 (5.2\%). Figure 3 reveals the distribution of the studies in terms of the type of publication and the research method used.

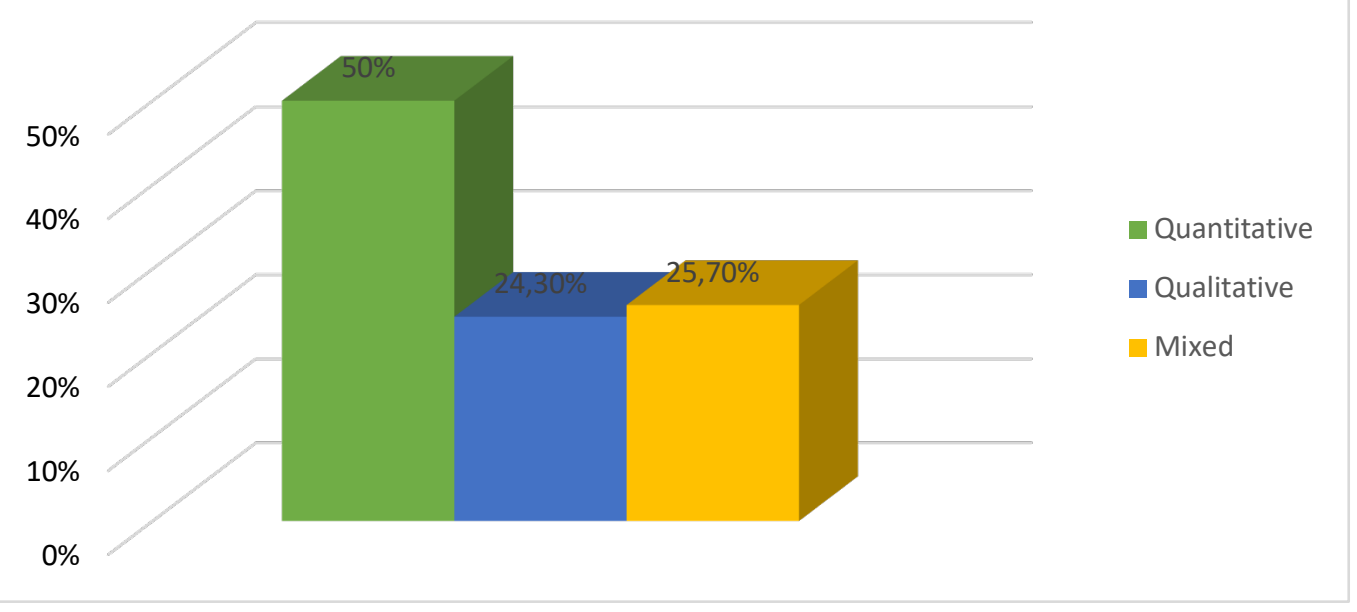

Figure 3: Distribution of research methods used in studies.

In the period covering 2010 and 2020, 50\% of the research studies about Laboratory Based Learning were carried out using quantitative research, $25.70 \%$ mixed research methods and $24.30 \%$ qualitative research methods. The distribution of the types of publication and research methods over the years is presented in Table 1.

Table 1: Distribution of publication types of research methods over the years

\begin{tabular}{|c|c|c|c|c|c|c|c|c|c|}
\hline \multirow{3}{*}{ Years } & \multicolumn{3}{|c|}{ Quantitative Research } & \multicolumn{3}{|c|}{ Quantitative Research } & \multicolumn{3}{|c|}{ Mixed Research } \\
\hline & Articles & $\begin{array}{l}\text { Master' } \\
\text { s Theses }\end{array}$ & $\begin{array}{c}\text { Doctoral } \\
\text { Dissertation } \\
\mathrm{s}\end{array}$ & $\begin{array}{c}\text { Article } \\
\mathrm{s}\end{array}$ & $\begin{array}{l}\text { Master' } \\
\text { s Theses }\end{array}$ & $\begin{array}{c}\text { Doctoral } \\
\text { Dissertation } \\
\mathrm{s}\end{array}$ & $\begin{array}{c}\text { Article } \\
\mathrm{s}\end{array}$ & $\begin{array}{l}\text { Master' } \\
\text { s Theses }\end{array}$ & $\begin{array}{c}\text { Doctoral } \\
\text { Dissertation } \\
\mathrm{s}\end{array}$ \\
\hline & $f$ & $f$ & $\mathrm{f}$ & $f$ & $f$ & f & $f$ & $f$ & f \\
\hline 2010 & 2 & 3 & - & 3 & 1 & 1 & - & 1 & - \\
\hline 2011 & 4 & 4 & 4 & 1 & - & 1 & 2 & 2 & 1 \\
\hline 2012 & 3 & 4 & 1 & - & 2 & - & 1 & 2 & - \\
\hline 2013 & 2 & 2 & - & 1 & 1 & - & 1 & - & 2 \\
\hline 2014 & 2 & 5 & - & 1 & 2 & 1 & - & 1 & 3 \\
\hline 2015 & 2 & 1 & 1 & 1 & - & - & 2 & - & - \\
\hline
\end{tabular}




\begin{tabular}{|l|l|l|l|l|l|l|l|l|l|l|}
\hline 2016 & 2 & 2 & 1 & 4 & 1 & - & 2 & 2 & 3 \\
\hline 2017 & 5 & 1 & - & 5 & 1 & - & 3 & 3 & 1 \\
\hline 2018 & 5 & 3 & - & 2 & 1 & 1 & - & 1 & 1 \\
\hline 2019 & 6 & 4 & - & 5 & 1 & - & 1 & 1 & - \\
\hline 2020 & 1 & - & - & - & - & - & - & 1 & - \\
\hline Tota & $\mathrm{f}$ & 34 & 29 & 7 & 23 & 10 & 4 & 12 & 14 & 11 \\
\hline & $\%$ & \multicolumn{2}{|c|}{50} & \multicolumn{2}{|c|}{24,30} & & & 25,70 & \\
\hline
\end{tabular}

As seen in Table 1, we can say that the most widely used method is the quantitative research method with a rate of $50 \%$. When viewed in detail, we can say that the quantitative method is mostly used in articles and master theses. On the other hand, we see that the quantitative research method was preferred most in 2011 ( $f=12$ ), while the mixed method was preferred in doctoral dissertations, especially in 2014 and 2016.

Figure 4 below shows the change in research methods preferred in the studies conducted over the years.

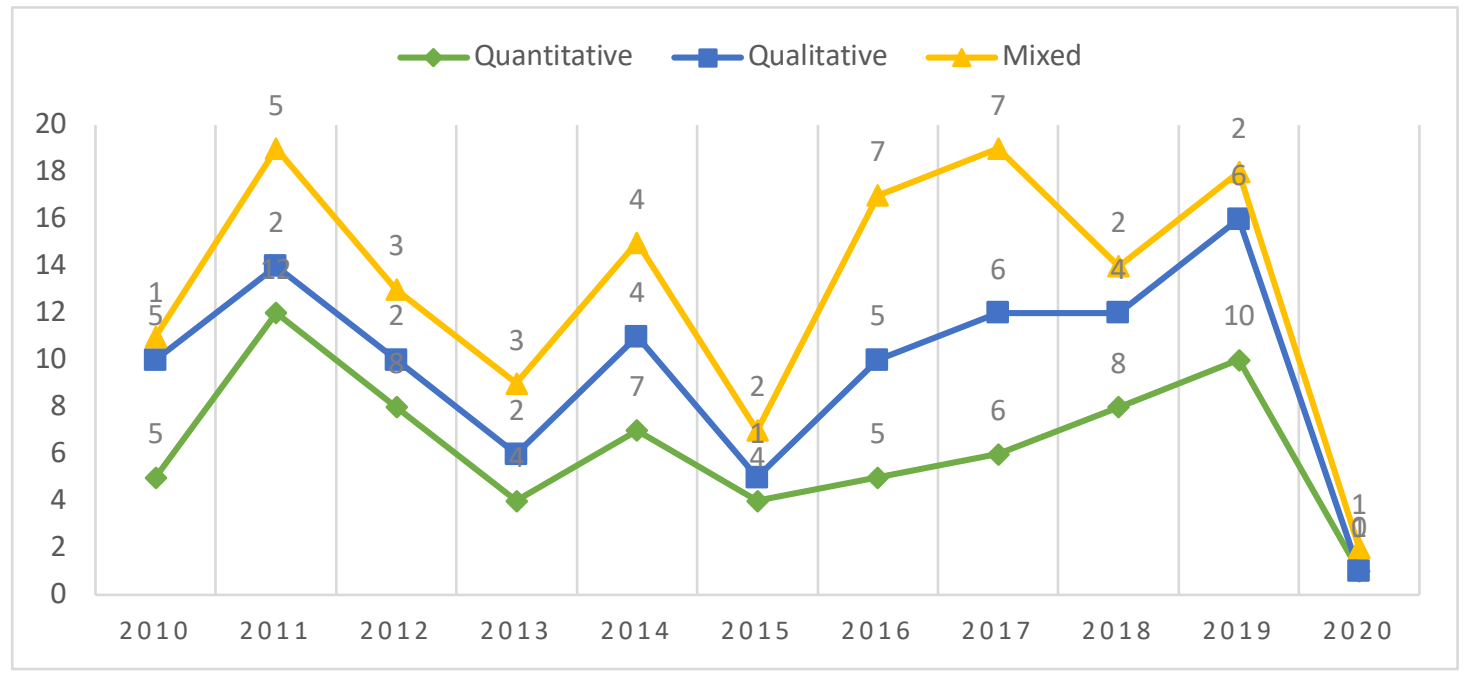

Figure 4: Distribution of Research Methods by Years

Although there was an increasing momentum in quantitative research between 2015 and 2019, it reached the highest number in 2019 ( $f: 10)$. There is an increasing trend in the number of mixed and qualitative studies as of 2016. The distribution in terms of the type of publication and the selected sample group is shown in Figure 5.

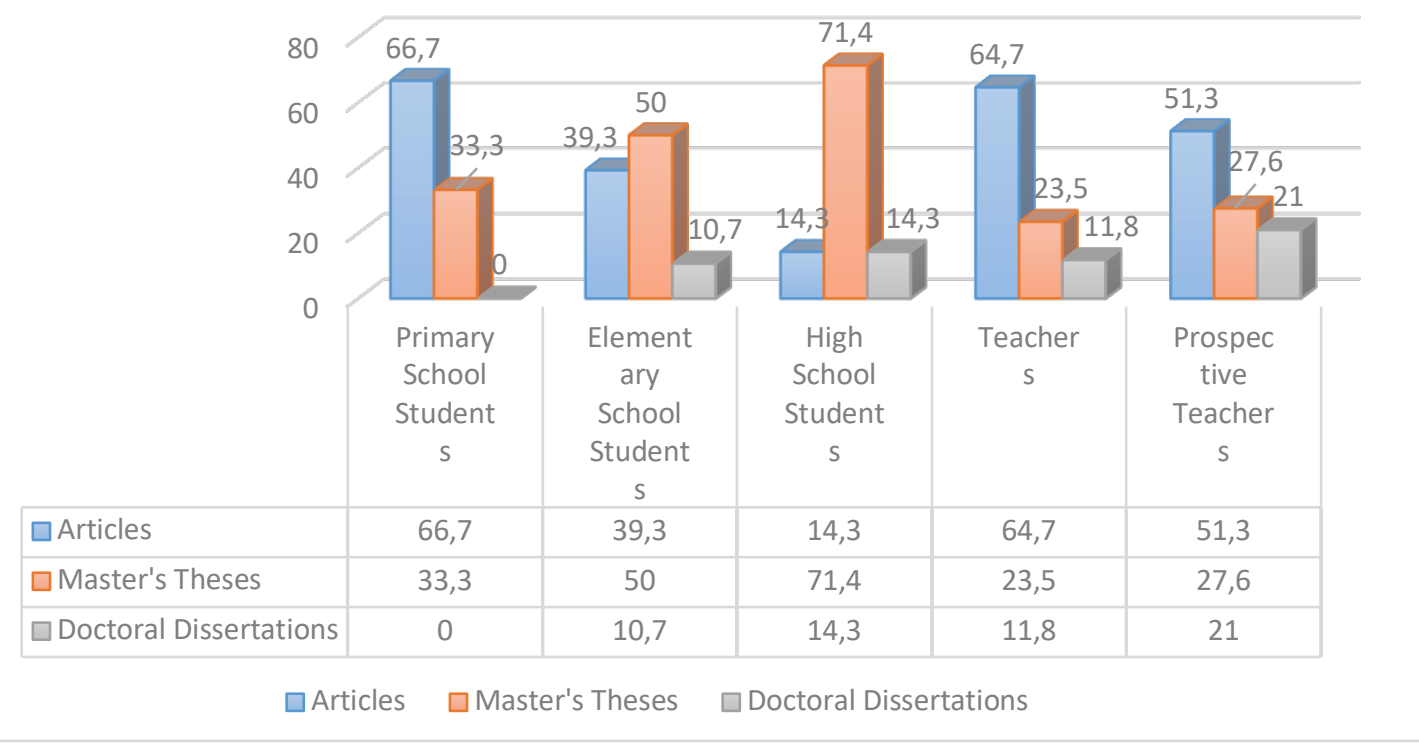


Figure 5: Distribution of publication types and selected sample groups

Considering the data of Figure 5, it is seen that studies were conducted with primary school students (66.7\%) and teachers (64.7\%), respectively. In master's theses, it can be said that secondary school students (50\%) follow high school students, preferably high school groups (71.4\%). In doctoral studies, it is observed that the most common sample group is prospective teachers (21\%).

The distribution of scientific research in terms of the type of publication and the data collection tool used is presented in Table 2.

Table 2: Distribution of the type of publication and data collection tools used

\begin{tabular}{|c|c|c|c|c|c|}
\hline \multirow{2}{*}{ Data Collection Tools } & \multirow{2}{*}{$\begin{array}{l}\mathbf{A} \\
\mathbf{f}\end{array}$} & M & D & \multicolumn{2}{|c|}{ TOTAL } \\
\hline & & f & $f$ & $\mathbf{F}$ & $\%$ \\
\hline Opinion form & 12 & 3 & 2 & 17 & 11,8 \\
\hline Observation & 3 & 4 & 2 & 9 & 6,3 \\
\hline Achievement Test & 10 & 14 & 4 & 29 & 20,1 \\
\hline Attitude scale & 9 & 5 & 5 & 19 & 13,2 \\
\hline Scientific process skill scale & 4 & 7 & 1 & 12 & 8,3 \\
\hline Self-efficacy belief scale & 1 & 0 & 3 & 4 & 2,8 \\
\hline Self-efficacy scale & 6 & 2 & 1 & 9 & 6,3 \\
\hline Inquiry based learning skill perception scale & 3 & 1 & 0 & 4 & 2,8 \\
\hline Motivation scale & 1 & 2 & 0 & 3 & 2,1 \\
\hline Document review & 5 & 5 & 0 & 10 & 6,9 \\
\hline Concept test & 6 & 3 & 3 & 12 & 8,3 \\
\hline Survey & 11 & 4 & 1 & 16 & 11,1 \\
\hline
\end{tabular}

(A: Articles, M: Master's Theses, D: Doctoral Dissertations)

In the light of Table 2 data, it can be said that the success tests (20.1\%) of the most popular data collection tool of Laboratory Based Learning studies between the years 2010-2020. The data collection tool that followed the achievement tests were attitude scales (13.2\%) and opinion forms (11.8\%). Considering the data collection tools used in the types of publication, the most frequently used data collection tool in the articles were the opinion forms $(f=12)$, success tests in master theses ( $f=14)$, and attitude scales in doctoral dissertations $(f=5)$.

Table 3.Distribution of scientific studies by publication type, sample group and units processed

\begin{tabular}{|c|c|c|c|c|c|c|}
\hline \multirow[t]{2}{*}{ Sample Group } & \multirow[t]{2}{*}{ Subject } & \multirow{2}{*}{$\begin{array}{l}A \\
f\end{array}$} & \multirow{2}{*}{$\begin{array}{c}M \\
f\end{array}$} & \multirow{2}{*}{$\begin{array}{l}D \\
f\end{array}$} & \multicolumn{2}{|c|}{ TOTAL } \\
\hline & & & & & $f$ & $\%$ \\
\hline \multirow{3}{*}{$\begin{array}{l}\text { Primary } \\
\text { School }\end{array}$} & World of Living Things & 2 & - & - & 2 & 1,4 \\
\hline & Electricity & 1 & 2 & - & 3 & 2,1 \\
\hline & General Subjects & 2 & 1 & 1 & 4 & 2,8 \\
\hline \multirow{7}{*}{$\begin{array}{l}\text { Elementary } \\
\text { School }\end{array}$} & Boiling and Evaporation & 2 & 1 & - & 3 & 2,1 \\
\hline & Density & 1 & - & - & 1 & 0,7 \\
\hline & Acid-Base-Salt & 1 & 1 & - & 2 & 1,4 \\
\hline & Science Concepts & 2 & 5 & 1 & 8 & 5,6 \\
\hline & General Subjects & 6 & 4 & 1 & 11 & 7,6 \\
\hline & Electricity & - & 1 & 1 & 2 & 1,4 \\
\hline & Force and Motion & - & 3 & - & 3 & 2,1 \\
\hline \multirow{6}{*}{ High School } & Photosynthesis & 1 & - & 1 & 2 & 1,4 \\
\hline & Laboratory applications & 1 & 2 & - & 3 & 2,1 \\
\hline & General Subjects & 1 & - & 1 & 2 & 1,4 \\
\hline & Undefined & - & 2 & - & 2 & 1,4 \\
\hline & Chemistry & - & 3 & - & 3 & 2,1 \\
\hline & Biology & - & 2 & - & 2 & 1,4 \\
\hline
\end{tabular}




\begin{tabular}{|c|c|c|c|c|c|c|}
\hline \multirow{11}{*}{$\begin{array}{l}\text { Prospective } \\
\text { Teachers }\end{array}$} & Force and Motion & 1 & - & 1 & 2 & 1,4 \\
\hline & Density & 1 & - & - & 1 & 0,7 \\
\hline & Undefined & 2 & - & 1 & 3 & 2,1 \\
\hline & Laboratory Use & 5 & 6 & 3 & 14 & 9,7 \\
\hline & Prediction-Observation-Research & 1 & 5 & 2 & 8 & 5,6 \\
\hline & Biology & 6 & - & 1 & 7 & 4,9 \\
\hline & Heat and Temperature & 1 & 4 & - & 5 & 3,5 \\
\hline & Physics & 4 & 1 & 2 & 7 & 4,9 \\
\hline & General Subjects & 3 & 1 & - & 4 & 2,8 \\
\hline & Chemistry & 9 & 1 & 2 & 12 & 8,3 \\
\hline & Science Concepts & 2 & 1 & - & 3 & 2,1 \\
\hline \multirow{7}{*}{ Teachers } & Behavior Theory & 1 & - & 1 & 2 & 1,4 \\
\hline & General Subjects & 1 & 1 & - & 2 & 1,4 \\
\hline & Physics & 2 & 2 & - & 4 & 2,8 \\
\hline & Chemistry & 1 & 1 & - & 2 & 1,4 \\
\hline & Biology & 1 & 1 & - & 2 & 1,4 \\
\hline & Laboratory Use in Science & 6 & 3 & 1 & 10 & 6,9 \\
\hline & Research and Inquiry Based Learning & 2 & 1 & - & 3 & 2,1 \\
\hline
\end{tabular}

(A: Articles, M: Master's Theses, D: Doctoral Dissertations)

According to the data of Table 3, which consists mostly of units and subjects that the researchers work on, it is observed that most studies were conducted with prospective teachers (46\%) in the period 2010-2020. In the studies carried out with prospective teachers, laboratory applications lesson $(f=14)$ was generally the subject. Laboratory applications are followed by the content of the chemistry course $(f=12)$.

\section{DISCUSSION AND CONCLUSION}

In the education of science, physics, chemistry and biology, the number of scientific studies based on Laboratory Based Learning has been carried out with the highest number of articles ( $f: 69)$ and at least the doctoral type ( $f: 22)$. When the types of studies conducted by years are examined, it is seen that the studies on Laboratory Based Learning were carried out at least in 2013 and 2015, and at most in 2017, with a large increase in 2016. In our country, the Science and Technology curriculum was reorganized in 2018 and the use of laboratories was considered a priority within the strategy of research and inquiry-based learning. Similarly, in the Science Course curriculum implemented in the 2018-2019 academic year, the statement of "Inquiry-based learning approach, in which each student is responsible for her own learning process, takes an active part in the learning process, and allows structuring information in their own mental processes, has increased the use of laboratories in the science course. Students assume the role of individuals who research, question, explain and discuss the source of knowledge"(MEB, 2017) is written. This explanation shows that the Laboratory Based Learning Approach is the basis of the curriculum and the primary basis of the learners in this process. It can be said that the increase in scientific research with the theme of Laboratory Based Learning in 2014 is due to the fact that the curriculum is structured with the effect of Laboratory Based Learning approach.

One of the limitations of this study is that the studies published during May 2020 are the subject of the research, and the publications after May 2020 could not be added to our research due to the pandemic. It can be said that the number of studies based on the Laboratory Based Learning approach in science education was at a low level in 2015 compared to other years. In terms of research management based on the studies examined during the research process, the quantitative research design, which reached the highest level in 2017 in the studies on Laboratory-Based Learning, was mostly selected by researchers in articles and master theses, while quantitative research was followed by mixed and qualitative research patterns, respectively. Studies conducted with various samples in many studies in the literature show that the quantitative research method is used more frequently by researchers, and this situation supports the finding of our research (Yenilmez \& Sölpük, 2014; Yavuz \& Yavuz, 2017; Tutar et al., 2017; Erdoğan et al., 2018; Sönmez, 2018; Avan, Çetinkaya \& Yılmaz, 2019). Koç (2016) states in their study conducted with the purpose of examination of master's theses, where evaluation of Turkey's primary and elementary education curriculums 
are reviewed, covering the years between 2005-2014, stated that the examined theses were carried out using quantitative methods at a high rate (f: $61 \%$ ). This finding supports the finding that quantitative research methods are preferred in $50 \%$ of laboratory-based learning-themed studies for all types of publications reached in our study. Quantitative research is frequently preferred by researchers in science education as well as in many disciplines. The reason why quantitative research methods are preferred over qualitative research designs is that the analysis of numerical data can be easily done so that concrete findings can be reached, the results of the study can be generalized, the number of accessible individuals in the sample group can be very high, and the advantages they provide in terms of time and cost expenses can be considered to be the determining factors (Göktaş et al., 2012).

It has been observed that mixed research methods have increased as of 2016 and 2017, and qualitative research has increased with 2017 and 2019. In doctoral dissertations on Laboratory Based Learning, the most used method by researchers was the mixed research method. In the studies conducted on the "Laboratory Based Learning" approach in the field of Science education covering the years 2010-2020, it was found that there were mostly prospective teachers as the sample group and the researchers studied the use of laboratory more; In addition, it has been determined that there are very few published studies, especially on subjects of density and force and motion. In studies conducted with secondary school students, it was determined that the subjects chosen by the researchers were generally "science concepts and general subjects". On the other hand, it is a striking finding that there are very few studies conducted with primary school students. In this case, the limited use of science education lessons and laboratory use in primary school shows that there are few studies done with these grade levels. The second priority sample group is elementary school students. "Science concepts" were mostly studied with students. Studies were conducted with students at the secondary school level for articles and master theses, and mostly on prospective teachers in doctoral dissertations. It has been observed that the number of studies conducted with prospective teachers is higher compared to teachers. The source of this situation may be the fact that it is important for prospective teachers to determine the subject of research on the subject of research before they start their professional life, and also that it is easy for researchers to reach prospective teachers, and prospective teachers are eager to participate in such studies.

When the scientific studies were examined, it was concluded that the most numerical achievement tests were used numerically as the data collection tool used in the researches, and attitude scales and interview forms were selected by the researchers after the achievement tests, and it is possible to reach this result in similar studies (Gülgün, Yılmaz, Avan, Ertuğrul Akyol \& Doğanay, 2019; Taş et al., 2013; Temel et al., 2014; Yavuz, 2017). When we classified the studies examined within the scope of the study in terms of the type of publication, it was seen that the most used data collection tool numerically in master's theses and article studies, while attitude scales were preferably used for doctoral dissertations. Factors such as easy access and saving time and cost, which can be considered as the reasons for the frequent use of quantitative research method (Temel et al., 2014), are also considered by researchers to be the reasons why success tests and attitude scales are widely preferred as data collection tools.

\section{SUGGESTIONS}

Research conducted by examining the studies on any discipline will guide researchers who will conduct future research on that discipline (Cohen et al., 2007). According to the results, the following suggestions are given for the researchers who will conduct scientific studies in the field;

1- Scientific studies on the Laboratory Based Learning approach abroad can be compared with the studies in our country.

2- As a result of the research, Laboratory-Based Learning-oriented studies can be carried out in primary school classes, all classes at the secondary school level and especially at the high school level as a sample group.

3- Qualitative and mixed research design is the least preferred research method in studies conducted in the light of research results. For this reason, the effect of all dimensions related to the approach can be examined in depth by using qualitative research methods in the future studies with the Laboratory Based Learning approach in the field of science education.

\section{Ethics Committee Approval Information}

This research was conducted in accordance with the code of ethics. Since research data is collected in 2019 and prepared in the form of document review, it does not require ethics committee permission.

\section{REFERENCES}


Al-Dasooqi, N., Bowen, J. M., Gibson, R. J., Sullivan, T., Lees, J., \& Keefe, D. M. (2009). Trastuzumab induces gastrointestinal side effects in HER2overexpressing breast cancer patients. Investigational new drugs, 27(2), 173-178.

Avan, Ç., Çetinkaya, M., \& Yılmaz, A. (2019). Out of school learning environment's effect of the secondary school students for science education and investigation of the participants' opinions. Journal of Strategic Research in Social Science, 5(3), 23-32. doi: 10.26579/josress-5.3.3.

Aydoğdu, B. (2009). The effects of different laboratory techniques on students? science process skills, views towards nature of science, attitudes towards laboratory and learning approaches in science and technology course (Doctoral dissertation, DEÜ Eğitim Bilimleri Enstitüsü).

Azizoğlu, N. ve Uzuntiryaki, E. (2006) Chemıstry laboratory anxiety scale. Hacettepe University journal of education. 30,55-62.

Baştuğ, A., Çıkılı, Y., Yalçın, P., \& Polat, R. (2002). The effect of the number of students on the level of achieving the goals of the science laboratory lesson (Erzincan Example). V. National Science and Mathematics Education Congress. Ankara: Metu Culture and Congress Center.

Bowen, G. A. (2009). Document analysis as a qualitative research method. Qualitative research journal, 9(2), 27-40. s.27.

Cohen, L., Manion, L. ve Morrison, K. (2007). Research methods in education (6th Ed.). New York: Routledge.

Çepni, S., Akdeniz, A. R., \& Ayas, A. (1994). The place and importance of the laboratory in science education (III). Contemporary Education Journal, 206, 24-28.

Çepni, S., Ayvacı, H. Ş. ve Bacanak, A. (2006). Science technology society (4th Edition). Celepler Publishing. Trabzon.

Çepni, S. (2011). Reflections of science, science and technology concepts on educational programs. S. Çepni (Ed.), In science and technology teaching from theory to practice. Ankara: Pegem Akademi.

Demirtas, Y., Yagmur, C., Soylemez, F., Ozturk, N., \& Demir, A. (2010). Management of split-thickness skin graft donor site: a prospective clinical trial for comparison of five different dressing materials. Burns, 36(7), 999-1005.

Erden, n. K. (2017). The metaphors Turkish teacher candidates use regarding the concept of "modernism". Electronic Turkish Studies, 12(29).

Erdoğan, G. D., Kaya Uyanık, G., Canan Güngören, Ö. (2018). An examination of postgraduate thesis written about active learning. Sakarya University Journal of Education, 8(1), 111-125.

Göktaş, Y., Küçük, S., Aydemir, M., Telli, E., Arpacık, Ö., Yıldırım, G., Reisoğlu, İ. (2012). Turkey's trends in educational technology research: content analysis of articles 2000-2009 period. Educational Sciences: Theory and Practice, 12(1), 406- 443

Güven, G., \& Sülün, Y. (2012). The effect of computer assisted instruction on academic success in 8th grade science and technology course and students' attitudes towards the course. Journal of Turkish Science Education, 9(1), 68-79.

Gülgün, C., Yılmaz, A., Avan, Ç., Ertuğrul Akyol, B., \& Doğanay, K. (2019). Determination of the views of primary, secondary school students' and workshops leaders' for the science fairs supported by TUBITAK (4007). Journal Of STEAM Education, 2(1), 52-67.

Kanlı, U., \& Yağbasan, R. (2008). The adequacy of the 7E model centered laboratory approach in developing students' scientific process skills. Gazi University Journal of Gazi Education Faculty, 28(1), 91-125.

Koç, E. S. (2016). Made of Investigation graduate thesis related evaluation of primary education program in Turkey. Abant Izzet Baysal University Journal of Education Faculty, Cilt 16 (1), 198-216

Koyuncu, M.S., Şata, M., Karakaya, i. (2018) Examination of presentations presented in education measurement and evaluation Congresses by Document Analysis Method. Journal of Measurement and Evaluation in Education and Psychology, Cilt 9, Sayı 2, 2018, $216-238$.

Köse, S. (2008). Laboratory based science teaching, pp: 46 - 89. Ö. Flood. (Ed.). New Approaches in Science and Technology Education. Pegem Akademi Publishing. Ankara.

MEB, (2005). Elementary science and technology lesson curriculum. Talim Terbiye Science Education Program, Ankara.

MEB, (2013). Elementary science and technology lesson curriculum. Talim Terbiye Science Education Program, Ankara.

MEB, (2017). Elementary science and technology lesson curriculum. Talim Terbiye Science Education Program, Ankara.

MEB, (2018). Elementary science and technology lesson curriculum. Talim Terbiye Science Education Program, Ankara.

O'Leary, Z. (2017). The essential guide to doing your research project. London:Sage

Özmen, H., Çepni, S., Ayas, A. P., Akdeniz, A. R., Yiğit, N., \& Ayvacı, H. Ş. (2005). Science and technology teaching from theory to practice (Doctoral dissertation, ed. S. Çepni, PegemA Publishing.

Özmen, H. ve Yiğit, N. (2006). Laboratory use in science teaching from theory to practice (2nd Edition). Memoir Publishing. Ankara.

Sönmez. S. (2018). Investigation of Turkey between the years 2013- 2017 in the biology education research. Journal of Academic Social Research, $6(74), 124-136$.

Sunal, D. W., Sunal, C. S., Sundberg, C. \& Wright, E. L. (2008). The importance of laboratory work and technology in science teaching. The impact of the Laboratory \& Technology on Learning and Teaching Science $K 16$ (s. 1-28). North Carolina: Information Age Publishing.

Taş, E., Şener, N., Yalçın, M. (2013). An analysis of scientific researches in the field of technology-assisted science education between the years 2005-2012. Journal of Computer and Educational Research. 1(1), 83-104.

Temel, S., Şen, Ş., Yılmaz, A. (2014). A content analysis related to the problem-based learning studies: The case of Turkey. Kastamonu University Kastamonu Education Journal,23 (2), 565-580.

Tunalı, i. (2010). Introduction to philosophy. Istanbul: Golden Books.

Tutar, M., Kurt, M., Karamustafaoğlu, O. (2017). Investigation of brain-based learning research in science education (Between 2000 and 2015). Karaelmas Journal of Educational Sciences,5(2), 236-249. 
Yenilmez, K., Sölpük, N. (2014). Analysis of thesis related to mathematics curriculum (2004-2013). Journal of Research in Education and Teaching ,3(2), 33-42.

Yıldırım, A. ve Şimşek, H. (2016). Qualitative research methods in the social sciences. Ankara. Distinguished Publishing.

Yanarateş, E., \& Yılmaz, A. (2020). Öğretmen adaylarının çevre duyarlıı̆ı kavramına yönelik metaforik algıları. Gazi Üniversitesi Gazi Eğitim Fakültesi Dergisi, 40(3), 1019-1050. https://doi.org/10.17152/gefad.699406

Yavuz, G., Yavuz, S. (2017). Related content analysis of thesis with project-based science education doctrine: The case of Turkey (2002-2014). Mehmet Akif Ersoy University Journal of Education Faculty. 43, 255-282. 